\title{
WHEN THE RISK IS URBAN PLANNING. A CASE STUDY IN EL CABANYAL (SPAIN)
}

\author{
A. Guardiola-Víllora ${ }^{1,2, *}$, L. Basset-Salom ${ }^{1,2}$ \\ ${ }^{1}$ Dept. of Continuum Mechanics and Theory of Structures, Universitat Politècnica de València, Cno Vera s/n, 46022 Valencia, \\ Spain, (aguardio, lbasset)@mes.upv.es \\ ${ }^{2}$ Research Centre PEGASO, Universitat Politècnica de València, Valencia, Spain
}

Commission II - WG II/8

KEY WORDS: Risk, Heritage, Urban planning, Cabanyal Ground Zero Area

\begin{abstract}
:
This paper presents the vicissitudes of a residential dwelling built in El Cabanyal in 1923 and how poor urban planning can be a risk. The building corresponds to one of the most common traditional typologies: a terraced house with masonry load bearing brick walls and timber floors, three storeys, a linear staircase attached to the party walls, a courtyard at the rear and a gable roof. In the past, this building, proved to be resilient, overcoming the risk of collapse in some important episodes which affected directly El Cabanyal: the air raid attacks of the Valencian coastline settlements during the Spanish Civil War and the floods occurred in 1949 and in 1957. In 1988, the building was listed in the catalogue of the General Plan with a protection grade 3. The special protection plan (PEPRI 2001) which was supposed to protect and rehabilitate El Cabanyal, projected the extension of Blasco Ibañez Avenue to the sea and consequently, the division of the neighbourhood in two halves, tearing down an important number of houses. Subsequently, the City council began to expropriate buildings facilitating their occupation by squatters. The level of degradation caused by the urban planning is such that this area is known as 'Ground Zero Area'. At the time of writing this paper, the building appears to be illegally occupied and in a bad state of preservation. After almost a hundred years facing different risks, poor urban planning appears to be the cause of the destruction of this heritage building.
\end{abstract}

\section{INTRODUCTION}

\subsection{Cabanyal quarter}

'El Cabanyal' is one of the old fishermen's quarters in Valencia. The origin of this historic settlement is set in the XIII century, after the arrival of James I the Conqueror, King of Aragon, to Valencia (which at that time depended officially on Caliph Bagdad al Mustàmsir), defeating Valencian inhabitants on September 28th, 1238 (Pastor, 2012).

The area developed in an independent village in which the inhabitants built their thatched fishermen's cabins (barracas) that used to line the beachfront. The grid pattern is one of the main valuable characteristics of the quarter: main streets and housing blocks were, since the origin, organised parallel to the waterfront, with an east to west orientation, allowing the houses to benefit from the cooling easterly winds coming from the sea in the summer.

Along history, the development of the settlement was based on the relationship with the sea and the growth of the economic activity of the harbour. During the 19th century, the Valencian harbour experienced a growing commercial activity and was expanded. Subsequently, thanks to the withdrawal of the coastline, the quarter grew parallel to the seashore. The fishing village soon became a popular zone for repose and leisure time. At the end of the century, summer visitors of Valencia started to rent or buy the fishermen and dock workers' houses, turning the area, named 'El Cabanyal', into one of the neighbourhoods of the spreading city of Valencia in 1897 (Figure 1). The old thatched fisherman's huts were replaced by two and three-storey townhouses in the styles in fashion at that time (mostly modernism but also baroque or eclecticism), while the prosperous Valencian bourgeoisie built new villas at the seafront. The new façades were covered with brightly coloured ceramic tiles in the style brought to Valencia by the Moors more than 1,000 years ago. Because of its strong village-like identity and uniqueness, El Cabanyal was declared as Historical Artistic Site in 1978 by the General Directorate of Artistic Heritage, Archives and Museums of the Ministry of Culture (Pastor, 2012).

\subsection{Case study}

The case study is focused on the residential building located at 239 (Figure 2) Padre Luis Navarro Street, (nowadays 233). This building has been selected as representative of many other Grade3 listed buildings built in the Cabanyal quarter before the Spanish War. They have an environmental value, constituting the urban scene where Grade-1 and Grade-2 buildings are located.

Its typology is one of the most common in the old fishermen quarter: a terraced house in a rectangular plot, with a linear staircase attached to the party wall, a courtyard at the rear and a gable roof with the ridge parallel to the façade. A sketch of how the distribution of the plan should be was proposed by Pastor (2012), corresponding to typology B (Figure 3).

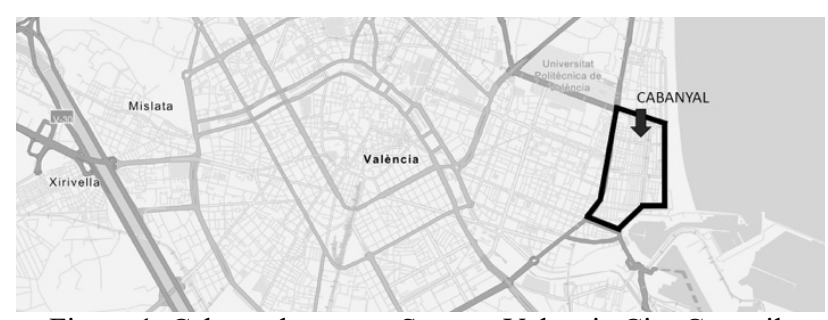

Figure 1. Cabanyal quarter. Source: Valencia City Council.

\footnotetext{
* Corresponding author
} 


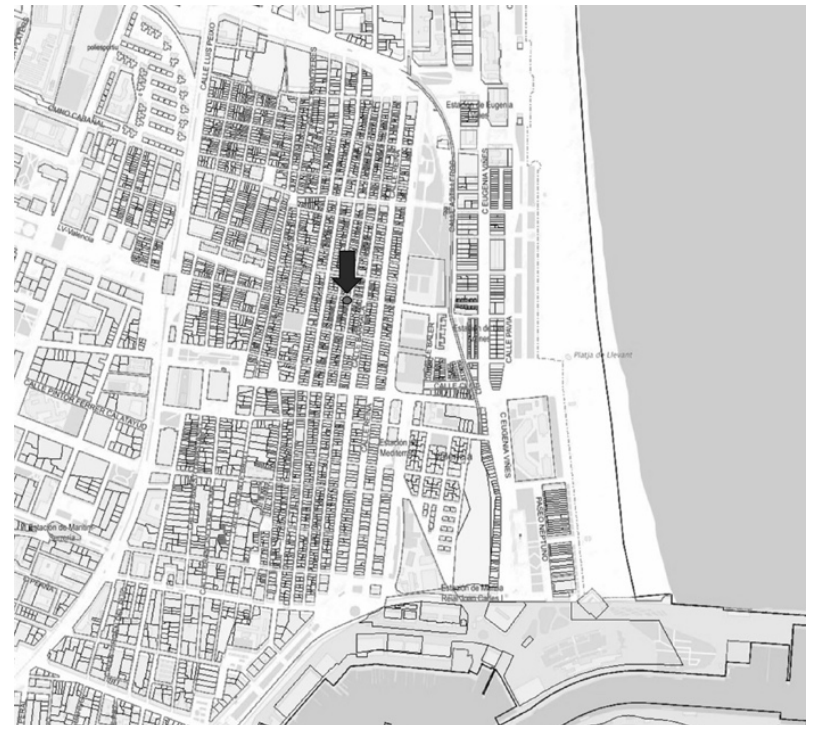

Figure 2. Position of the building. Source: Cadastral Database 2019.

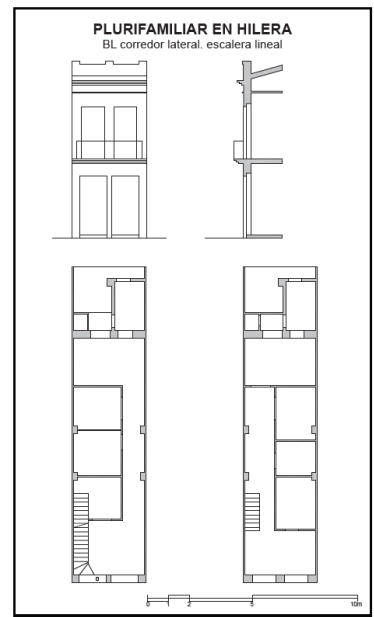

Figure 3. Typology B: plans. Source: Pastor, 2012.

\subsection{Spanish Civil War}

In July 1936, the Spanish Civil War broke out. Valencia was the third most bombed city in Spain, being the harbour one of the main air raid targets, because of its strategic value (Solé, 2003). Following the new strategy of frightening and demoralizing the civilian population, the coastline settlements suffered countless attacks, not only from the sea but also from the air (Figure 4) keeping the population under a constant threat. (Collado, 2017). As a result of the above-mentioned air raids, this residential building, like many others, was damaged.

At the end of the war (1st April 1939), once the new regime was established, the Spanish cities started rebuilding processes.

To proceed with the reconstruction of the damaged buildings, a repair permit was requested. To apply for a repair permit and financial aid, a report on the assessment of damage suffered by the buildings during the bombings and a reconstruction project was compulsory.

The original Technical Report (in Spanish) and the Building Permit Application of the building under study (see original location plan in Figure 5) are shown in Figures 6 and 7, respectively. In this report it can be read that, according to the Architect Victor Gosálvez, the stairs were destroyed, as a consequence of the bombing and both, internal walls and façade walls, had cracks. The ceiling panels fell, and the roof was damaged.

The proposed intervention consisted in building new stairs, repairing the cracks and the ceilings, fixing the roof, the gutters and the balcony and finally painting the façade. A note about the compromise of using original materials was added at the end of the document signed in July 1941.

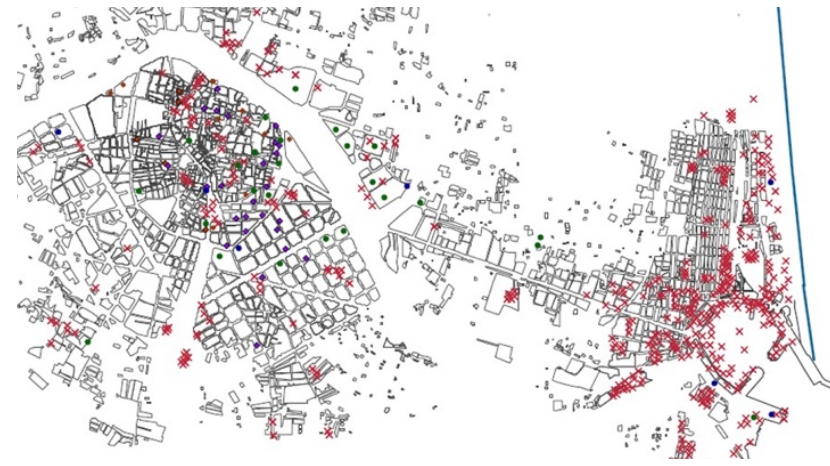

Figure 4. Bombing of Valencia. Source: Peinado, 2015.

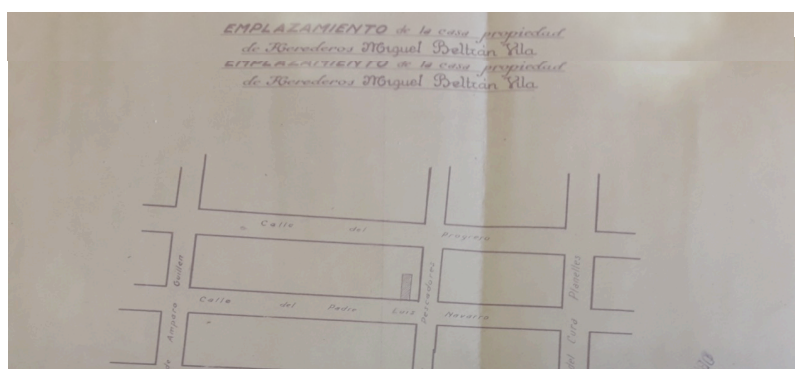

Figure 5. Building location plan. Source: Municipal Historical Archive of Valencia (AHMV) 1941.

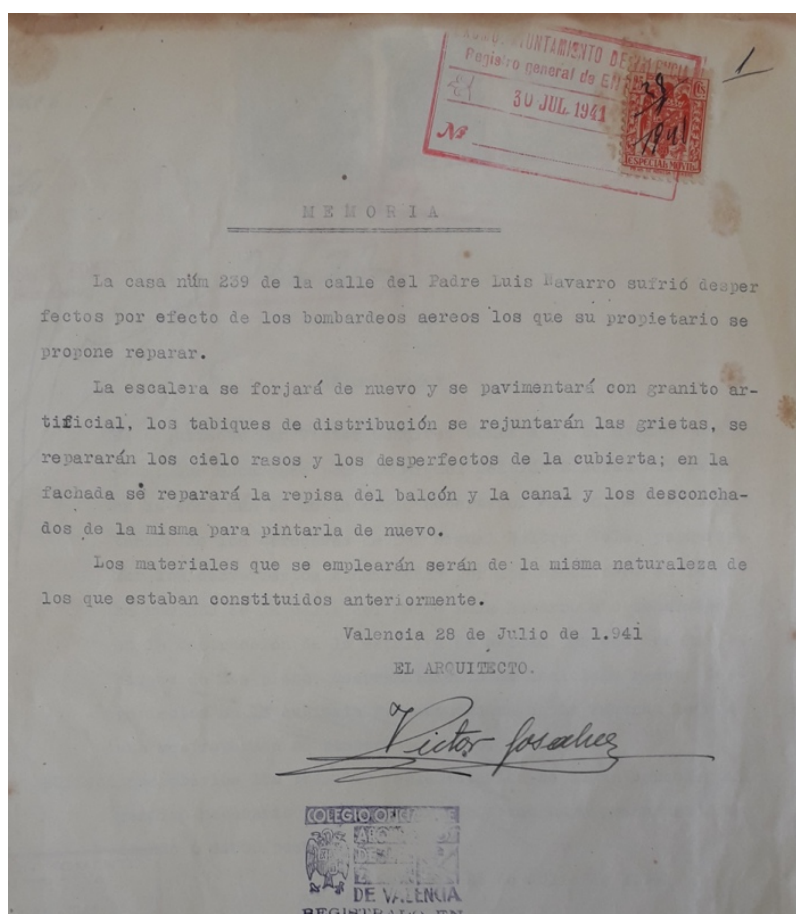

Figure 6. Building Technical Report. Source: AHMV 1941. 


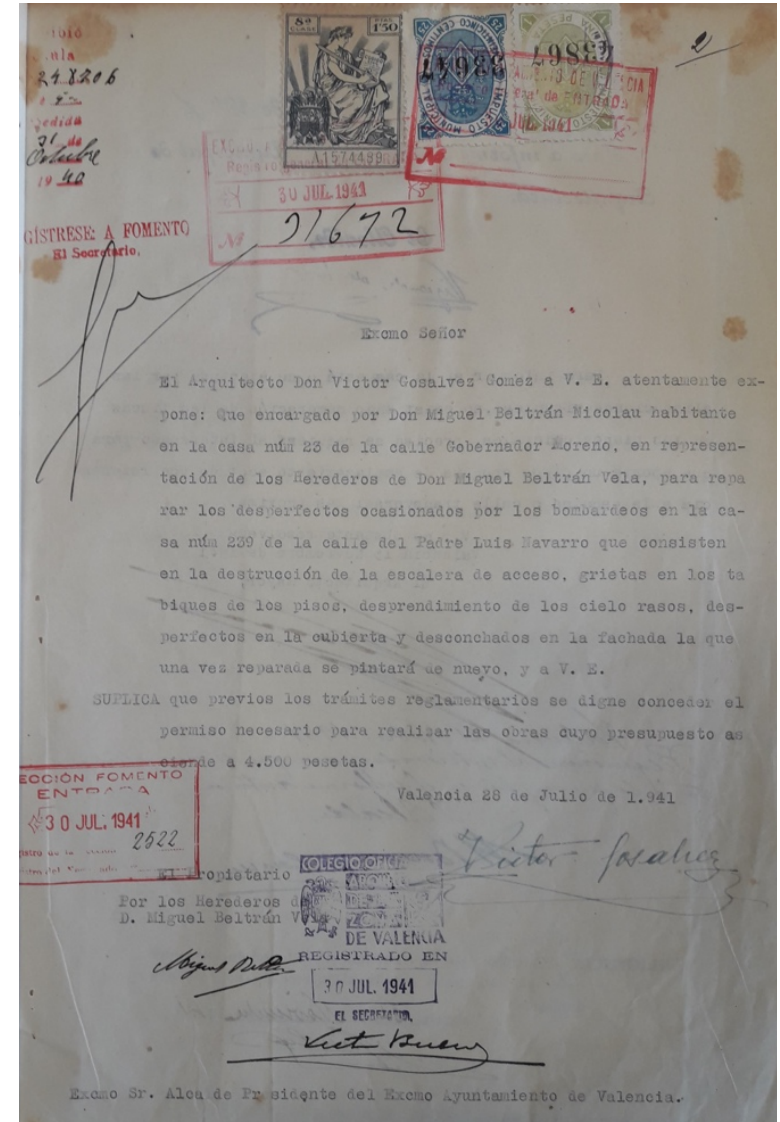

Figure 7. Building Permit. Source: AHMV 1941.

\subsection{Floods}

Only sixteen years later, on the 14th October 1957, a natural disaster occurred in Valencia: The river Turia overflowed affecting the city and particularly El Cabanyal neighborhood, where some houses collapsed.

The newspaper 'Las provincias' published the following data:

Valencia has suffered what has undoubtedly been the most serious catastrophe in its history: a double avenue of the Turia River, on October 14th, has caused a total of 81 deaths and damages, in the city and in the province, estimated at no less than 10,000 million pesetas. More than 12,000 shops have been affected. More than 3,500 families have been left homeless, more than 5,800 homes have been destroyed, thousands of tons of mud have been left in the streets and squares (Las Provincias, 1957).

Despite not having documented evidence about the effect that this flood had in the building under study, Figures 8 and 9 show that all the quarter was flooded, with the streets acting as rivers draining the water into the sea. Graphic documents about some houses in the Cabanyal quarter, totally destroyed by the flood, can be seen in Figure 10.

The picture in Figure 11, taken in front of number 179 at Padre Luis Navarro street (next building block toward south) shows that all the population, included the army, were involved in the cleaning of the tons of mud that covered streets, squares and gardens.

Despite the catastrophic flood, this building proved to be resilient, overcoming this natural risk.

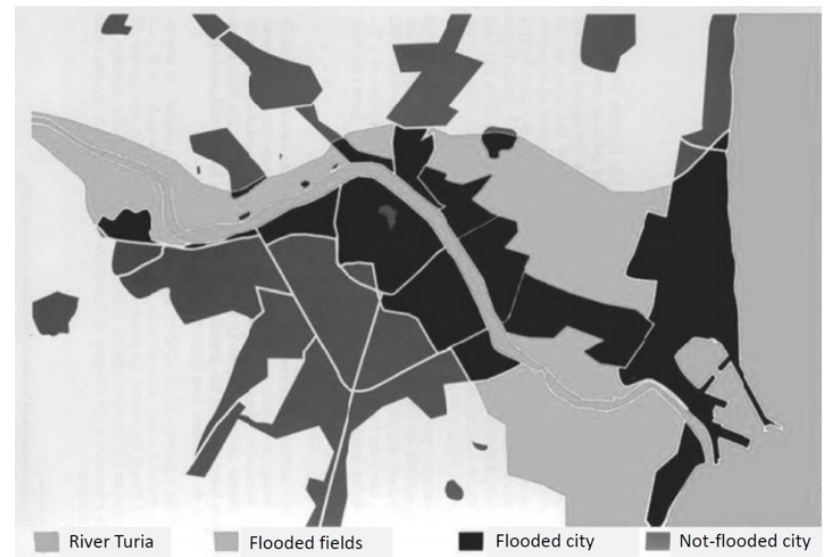

Figure 8. Valencia: flooded areas. Source: Ateneo Mercantil de Valencia. Grupo de análisis 'Impulso a Valencia' 2014.

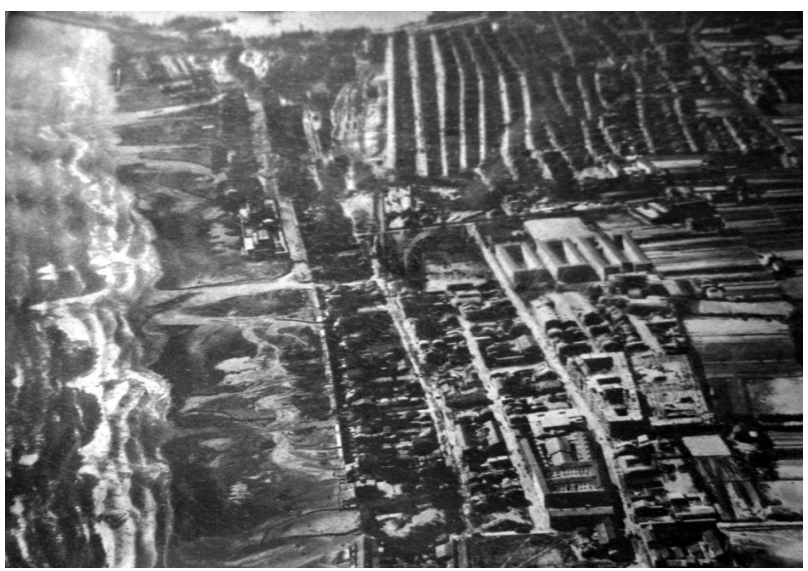

Figure 9. Floods in Cabanyal, US Navy. Source: Pérez 2008.

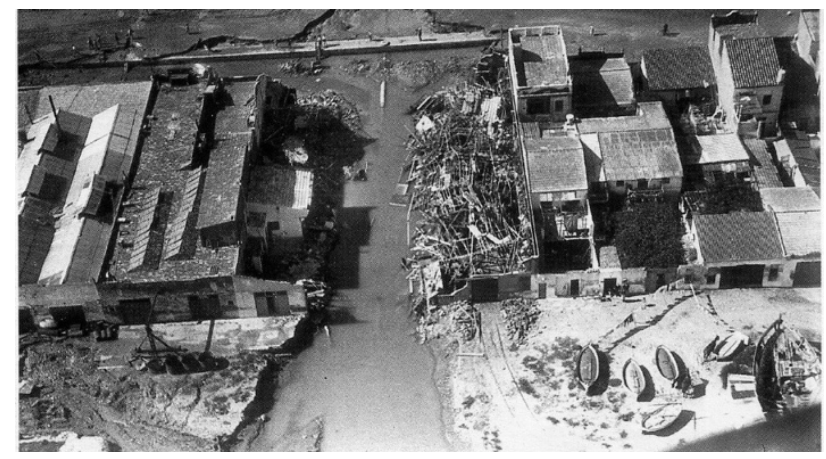

Figure 10. Houses at Eugenia Viñes and Pavía streets. Source: Pinito 2017.

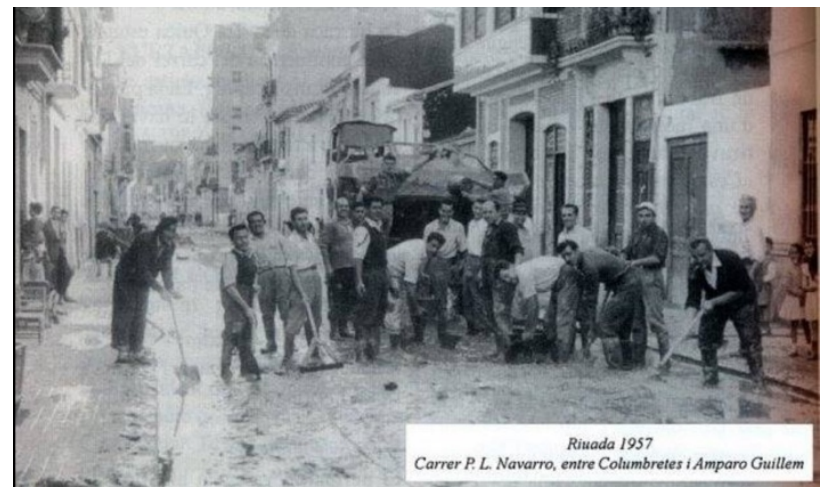

Figure 11. Padre Luis Navarro street mud cleaning after the floods. Source: Alos 2016. 


\section{URBAN PLANNING}

\subsection{Expansion of the city at the end of the XIX century}

In 1853, Valencia, with more than 100.000 inhabitants, started its expansion, demolishing the medieval walls in 1865 and drafting new planning proposals that followed the modern urban theories at that time. According to these innovating ideas, several projects proposed to trace a wide boulevard to connect the city centre with the beach, linked at that time only through the Port's Avenue. This new boulevard would receive the name of 'Paseo al mar' (meaning promenade to the seafront).

Some of the projects, planning the connection of the old town with the Cabanyal neighbourhood and the beach, were drafted by Manuel Sorni Grau in 1865 (Boira, 2000), Casimiro Meseguer in 1883 or José Pedrós in 1931 (Pastor, 2012, Hervás 2017). However, due to the lack of funding and the outbreak of the Spanish Civil War in July 1936, none of these projects took place.

At the end of the Spanish war, the reconstruction of the city started, and new general urban plans were drafted, bringing again to light the connection of the city with the sea, without invading, as in the previous proposals, the Cabanyal street tissue.

\subsection{The sixties: The housing bubble}

After the 1957 big floods, once normal life rhythm was recovered, a new General Plan was proposed, Plan General de Valencia (1966). This plan was the starting point of the typological and environmental degradation of El Cabanyal since it allowed unusual typologies in the area as well as an increase in the buildability and therefore, of the number of storeys (Pastor, 2012).

The connexion of the city with the seafront is an issue that remained unsolved after the end of dictatorship when democracy arrived. The extension of the boulevard through the old fishermen's quarter and its preservation has been a controversial topic until the beginning of the XXI century.

On the 22nd February 1978, a resolution of the General Directorate of Artistic Heritage, Archives and Museums of the Ministry of Culture was published declaring six zones in Valencia as Historical Artistic Sites, being El Cabanyal one of them. Ten years later, in December 1988, the approved Plan General de Ordenación Urbana de Valencia (hereinafter PGOU88) recognised El Cabanyal as Historical Artistic site and declared that a specific planning to regenerate the area and solve the access from the city centre will be developed, preserving the building typologies and the street patterns. A catalogue of the listed buildings to be protected was included in the documents of the PGOU88.

The original core of the expansion of El Cabanyal was declared an Asset of Cultural Interest (BIC), by a decree of the Valencian Regional Government on May 3rd, 1993, because of the architectural, urban, environmental and historical values.

However, and despite the BIC declaration, on July 24th, 1998, the local government started the draft of a special protection and rehabilitation plan which established the extension of 'Blasco Ibáñez avenue' (initially named 'Paseo al Mar') to the sea. This avenue crossed El Cabanyal neighbourhood and divided it into 2 halves, as shown in Figure 12a.
This proposal implied tearing the grid pattern of the historical Artistic Site and the destruction of about 500 buildings, comprising 1651 homes, (Hervás 2017) many of them listed with the status of special protection in the PGOU88, as can be seen in Figure 12b. This plan was finally approved as Special Protection and Rehabilitation Plan PEPRI (Plan Especial de Protección y Reforma Interior del Cabanyal-Canyamelar) on April 2nd, 2001. In this new proposal, the number of listed buildings was significantly reduced, so that, none of them were included in the extension of the avenue invading El Cabanyal.
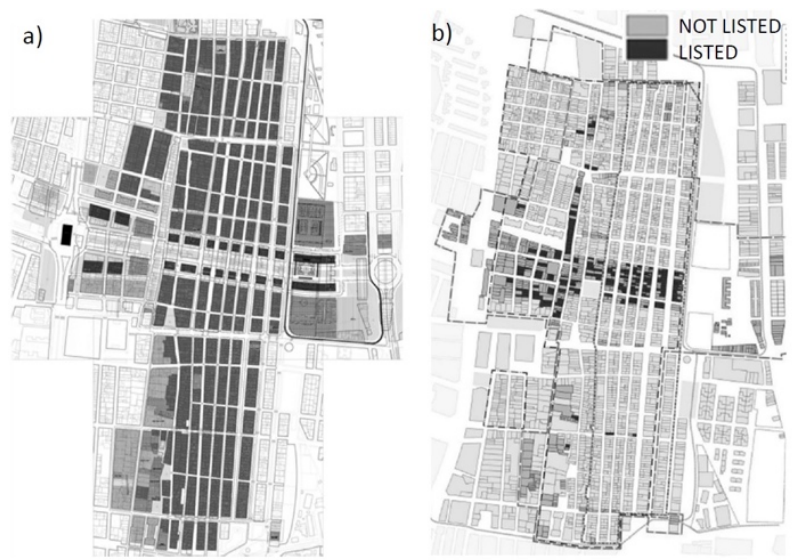

Figure 12. a) PEPRI 2001 Proposal; b) Buildings to be demolished (in black buildings listed by PGOU88). Source: Herrero 2016.

\subsection{Century: City Council strategy and judicial appeals}

According to the Law of Valencian-Cultural Heritage (18/07/1998), the project of extending the Avenue Blasco Ibáñez, as planned in the PEPRI 2001, clearly contravened culture and legislation but, above all, the will and way of life of the inhabitants.

Several judicial appeals with opposite results came about regarding this plan, with Court decision, in some cases, in favour of the neighbours and, in others, in favour of the local City Council. The City Council took profit of this period and created public corporations which bought the buildings to be demolished. The fact of being abandoned contributed to their decline and led to their occupation by squatters and drug dealers. The affected area was degraded and began to be known as Cabanyal's Ground Zero Area. In addition, the local and regional government modified the regional Law of ValencianCultural Heritage (19/7/2004) allowing the demolition of the buildings in this area.

In 2009, the implementation of the PEPRI 2001 was suspended by the Ministry of Culture, who demanded the plan to be adapted to guarantee the protection of the Historic artistic Site. After minor changes, in April 2010, the city council approved and started the demolition of the houses affected by the plan. When the Court stopped this action, about 125 houses had been demolished, including 28 with the tiled style (Tarín, 2013).

After the local elections in 2015, the new city council ended the demolitions, repealing the PEPRI 2001 (July 2016). A new Special Protection Plan of El Cabanyal (hereinafter PEC) was developed to protect and recover the affected area. The revised version of this plan was exposed for public information in February 2019 (Ayuntamiento de València 2019). 
Since then, the plan to extend Blasco Ibañez Avenue was repealed, planned evictions have taken place in public and private residential buildings (Las Provincias 2016a, Las Provincias 2016b, La Vanguardia 2016, El Mundo 2016), public residential buildings, infrastructures and facilities have been built, renewed or retrofitted (Ayuntamiento de Valencia 2016, Levante-emv 2017, Las Provincias 2018; Plan Cabanyal-Canyamelar 2019a, Plan Cabanyal-Canyamelar 2019b), public buildings have been demolished (Plan Cabanyal-Canyamelar 2019c, 2019d), public residential buildings have been offered for sale (Levante-emv 2016, Las Provincias 2016c) and different funding programs to make residential building improvements, based on State or European subsidies, have been approved (Ayuntamiento de Valencia 2016, DOGV 2017, 2017, Generalitat Valenciana 2017, Las Provincias 2018).

\section{CURRENT STATUS OF PADRE LUIS NAVARRO STREET No. 233}

\subsection{Cadastral data}

According to the Cadastral Database (figure 13) the three-storey building was built in 1923 and is divided into two independent properties. A small dwelling ( $39 \mathrm{sqm}$ ) in the ground floor and a second one with direct access from the street in the first and second floors (77 sqm). The top view in this picture shows a small courtyard (1 sqm) and a one-floor construction at the rear of the building.

Being the dimensions of the plot $3.40 \times 11.5 \mathrm{~m}$, it can be classified according to Pastor (2012) as a 'media escalá', equivalent to half original plot.

Considering the constructions in the Cadastral Database, the dimensions of the plot, and the residential typologies studied by Pastor (2012) a probable original plan distribution has been drawn in figure $14 \mathrm{a}$, with a $15 \mathrm{~m}^{2}$ rear courtyard, while figure $14 \mathrm{~b}$ shows the current construction of the ground floor.

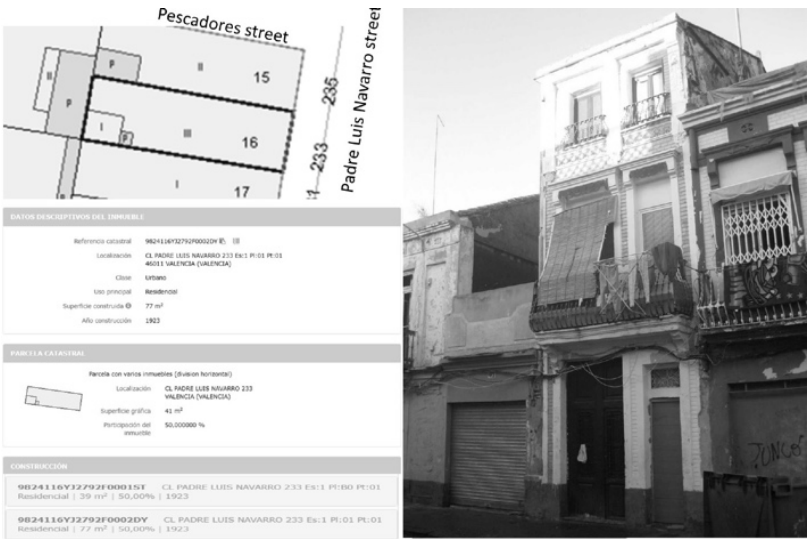

Figure 13. Cadastral file. Source: Cadastral Database.
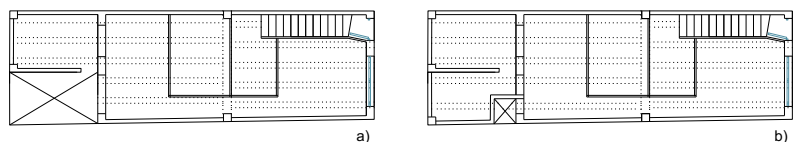

Figure 14. a) Probable original plan b) current plan. Credits: author's proposal.
However, considering the roof's view in figure 15, where it is evident that the construction at the end of the courtyard has a different roofing, it is possible that the courtyard was initially designed $3.4 \mathrm{~m}$ wide.

\subsection{PEC data}

The plans included in the initial information document of the PEC, state that:

- the building is listed with a protection grade-3 (Figure 16a) which means that having an environmental value, its façade and volume must be preserved.

- the maintenance state is bad (Figure 16b)

- the number of inhabitants registered in the census is between 1 and 20 (Figure 16c)

- the property is not public (Figure 16d).

Despite being listed, no catalogue including the main features of the buildings that must be preserved and the improper alterations to be reversed have been drafted yet.

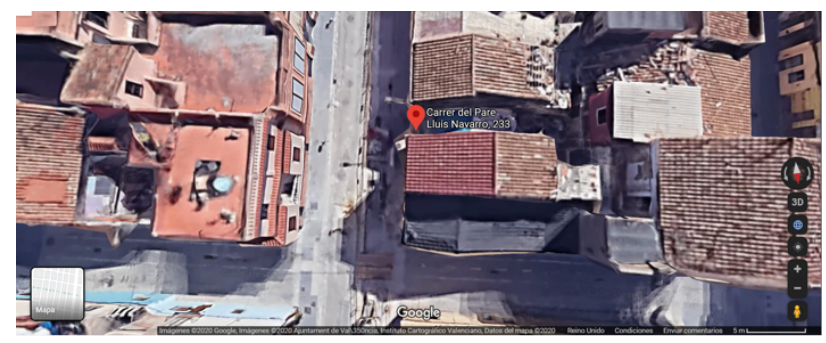

Figure 15. Source: street view.
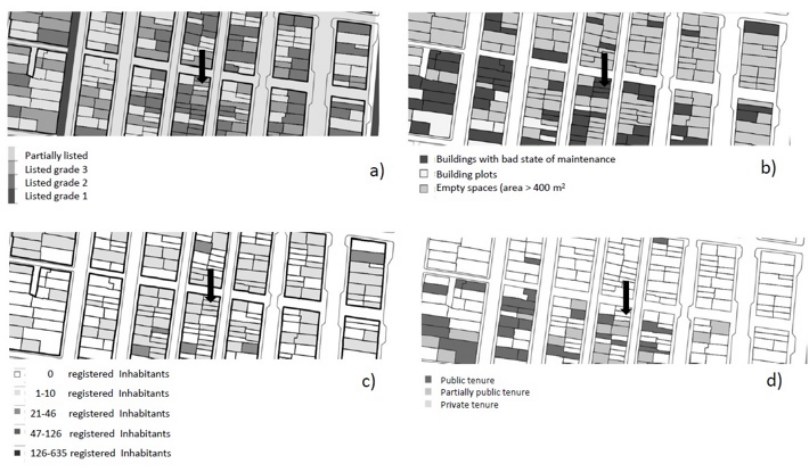

Figure 16. a) Listed buildings; b) State of maintenance; c) Number of inhabitants; d) Tenure status. Source: PEC 2019.

\subsection{In situ inspection}

One of the first characteristics to be noticed in the inspection is the number of storeys of the building under study (an aerial view of the block can be seen in Figure 17), specially compared to older buildings in the same block with only two storeys. Being a common practice, at the beginning of the XX Century, to increase the number of floors of the existing buildings, both party walls have been analysed (figure 19) concluding, contrary to what might initially be assumed, that it was initially built with three storeys.

The number of storeys and the year in which the aggregate's dwellings were built, retrieved from the Cadastral Database, have been drawn in figure 18 . 
The main façade follows the openings layout guidelines pointed out by Pastor (2012) for Type B typologies. The ground floor is organised with two independent entrances with different dimensions: on the right, the small door opens to the stairs leading to the first floor while the double door on the left opens to the ground floor household.

The same layout is repeated in the first floor, with a balcony connecting both openings. Finally, the windows on the second floor were designed with the same dimensions (Figure 19).

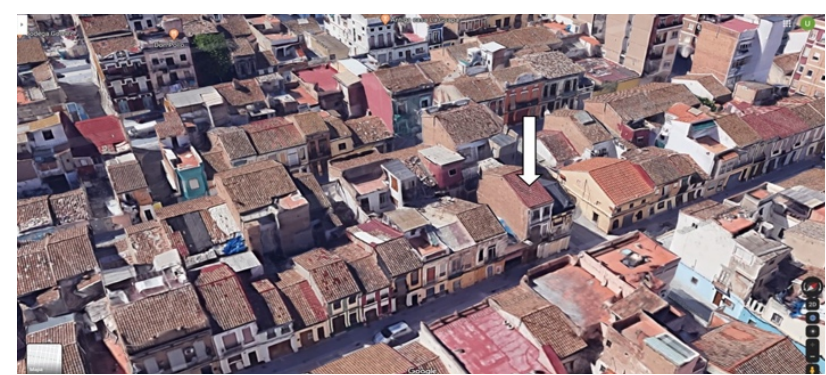

Figure 17. Padre Luis Navarro st Aerial view. Credits: Imágenes (C)2020 Google, (C2020 Ajuntament de València.
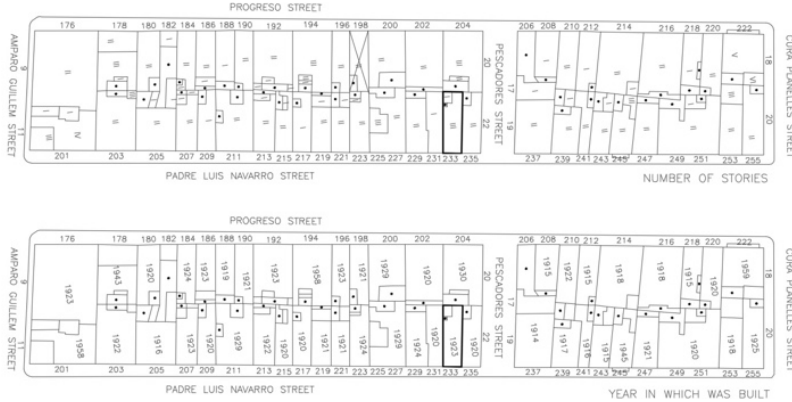

Figure 18. Number of storeys and age. Credits: The authors.

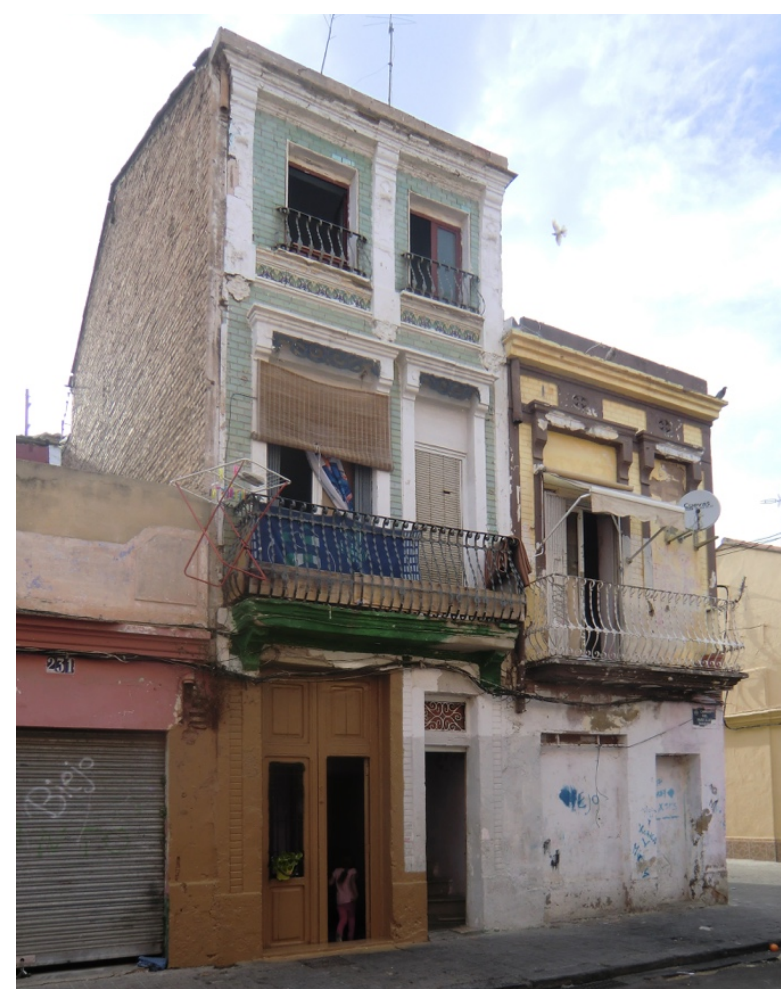

Figure 19. Padre Luis Navarro Street no 233. Credits: The authors, 2019
To guarantee the conservation and enhancement of El Cabanyal, preserving the traditional art and crafts skills, the opening on the right side of the first floor should recover its original dimensions. Additionally, the following elements of the façade should be preserved:

1.The ceramic decorative frieze between the first and the second floor together with the green ${ }^{1}$ tiles and their bonding style (figure 20). These tiles and pattern can be seen in many buildings along the quarter (e.g. in the same block at 209 and 219 Luis Navarro st and 196 Progreso st).

2.The ironwork of the balcony and windows. This design (figure 20) is repeated along the balconies and windows of the quarter.

3. First floor blind protections. Being Valencia a Mediterranean city, it was common practice to install outdoor wood chick blinds for blocking the summer sunlight heat. The houses of El Cabanyal used to protect these blinds with wrought iron elements like those in figure 21.
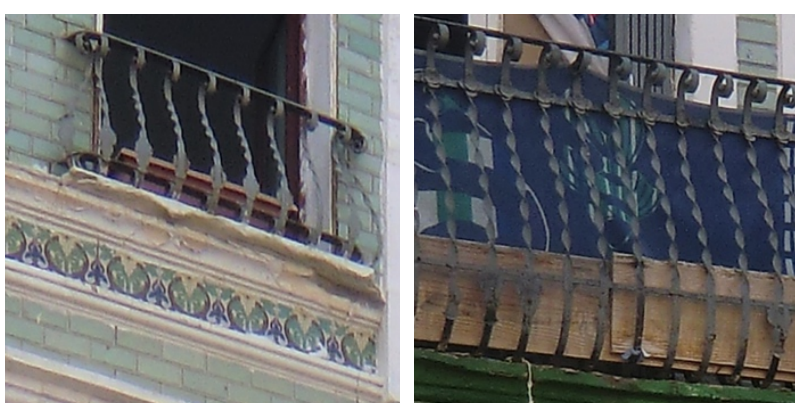

Figure 20. Tiles and ironworks. Credits: The authors.

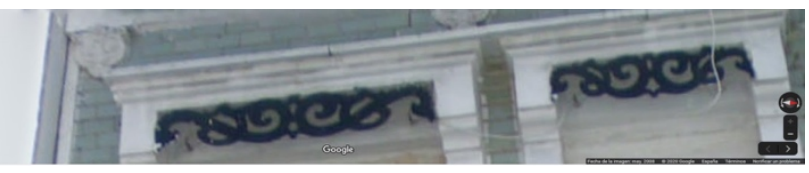

Figure 21. Blinds' protections. Credits: Street view 2008.

Finally, it must be pointed out that at the moment of writing this paper, the house seemed to be inhabited by squatters with an appalling state of maintenance (Figure 19 and Figure 22), being this condition similar to the adjacent houses which don't seem to be in a better state (Figure 23).

In the building permit in Figure 7, it can be read that in 1941 the building ownership of 233, Padre Luis Navarro street was shared between Mr. Beltran Vela's heirs, being his eldest son, Mr. Beltran Nicolau, who hired the architect. Mr Beltran Nicolau was registered at Gobernador Moreno st, nowadays Mediterráneo's st (Claramunt, 2015), one of the main streets in El Cabanyal quarter, confirming that El Cabanyal's inhabitants were fond of their quarter and wish to remain in the neighbourhood, being the irresponsible urban planning the main cause of abandon and decay.

The bad state of maintenance is one of the parameters which influence the seismic vulnerability of the building. With a vulnerability index value $\left(\mathrm{V}_{\mathrm{I}}\right)$ between 0.8 and 1 , it has been classified as vulnerability class B (Basset-Salom, GuardiolaVíllora, 2020). Consequently, even though Valencia is located in a low-to-moderate seismic zone, the high vulnerability of this building foresees important seismic damages in the occurrence of a seismic event.

${ }^{1}$ Pantone $351 \mathrm{C}$ or $344 \mathrm{C}$ 


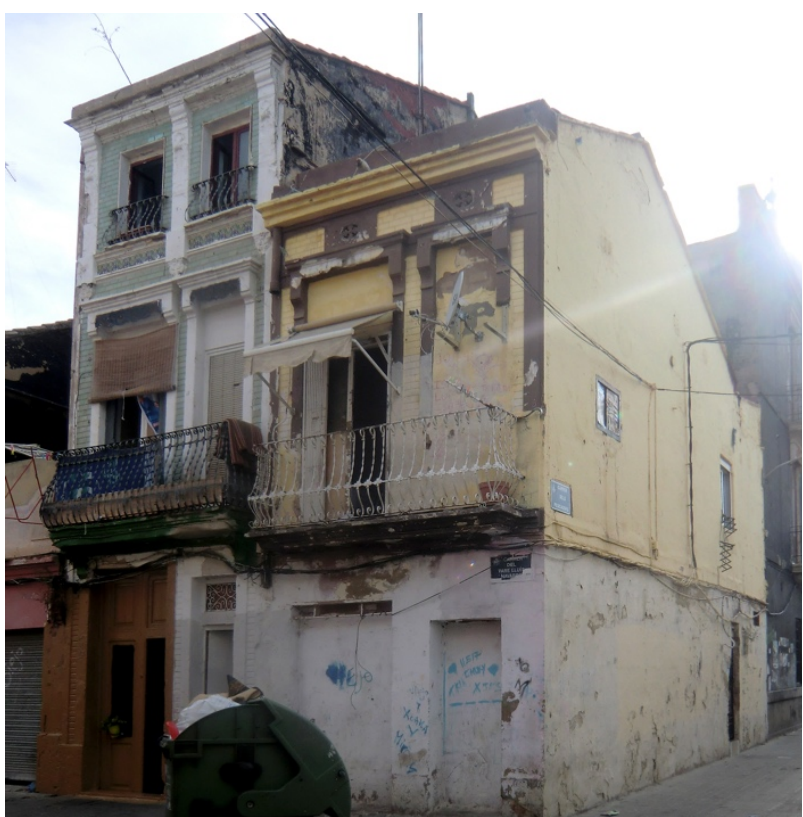

Figure 22. Padre Luis Navarro Street no 233. Credits: The authors, 2019.

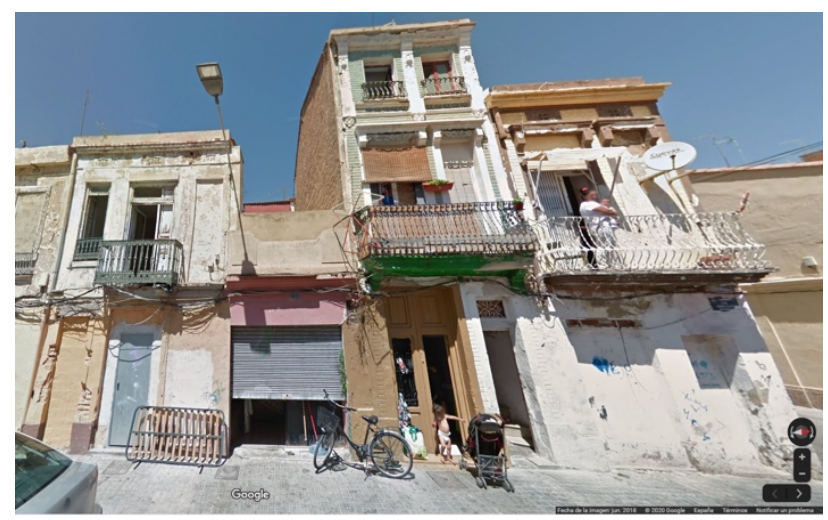

Figure 23. Padre Luis Navarro Street no 233. Source: Street View. Date of the image: Jun 2018.

In the same document, the expected mean damage index values (Dsm) estimated for that building, ranged from 0.5 to 1 in the case of an intensity VI seismic event; from 1 to 1.5 for an intensity equal to VII and, finally, from 1.5 to 2 for an intensity between VII and VIII.

Considering the abovementioned data and taking into account the listed status of the building, it is a must to point out that not only economic losses can be expected, but also irreplaceable cultural and heritage value will be lost.

\section{DISCUSSION AND CONCLUSIONS}

In this paper the case study of a residential listed building threatened by natural and human induced hazards (as many others in the quarter) has been presented.

The building was built nearly 100 years ago with masonry bearing walls and timber floors, following the typologies at the moment, at Padre Navarro Street in El Cabañal quarter of Valencia (Spain).

Being a resilient building, it was able to recover from the Spanish War bombings and the 1957 catastrophic floods.
However, nowadays, its existence is at risk, due to the state of degradation and decay, as a result of a poor redevelopment plan that sentenced the residential buildings of Ground Zero Area to demolition.

Nearly five years after the repeal of PEPRI 2001 some blocks in the area have not been able to recover. Not being public tenures, the retrofitting process is more difficult and slower.

The heritage of a residential neighborhood includes both, buildings and their inhabitants, and neither of them should be neglected. Maintaining the residential use and, above all, the homeowners, contributes to improve the quality and sustainability of the urban tissue.

Heritage conservation strategies should identify, assess, protect and enhance the historic, cultural, and artistic values of the buildings. Modern societies assume that damage in heritage buildings can be caused by degradation or natural hazards, therefore strategies to minimise its effects should be drafted. On the other hand, this paper presents a human induced risk that threatens the built environment producing decay and destruction.

This building is an example that can be used as a reminder and a complaint addressed to politicians and urban planners about what should not be done.

\section{ACKNOWLEDGEMENTS}

This paper is related with the research project "RISK-Terra. Earthen architecture in the Iberian Peninsula: study of natural, social and anthropic risks and strategies to improve resilience" (RTI2018-095302-B-I00), funded by the Spanish Ministry of Science, Innovation and Universities.

\section{REFERENCES}

Alos, A., 2016. Cabañal. Riada 57

https://www.facebook.com/groups/276591349194519/search/?q uery $=\mathrm{CABA} \% \mathrm{C} 3 \% 91 \mathrm{AL} \% 20 \mathrm{RIADA} \% 2057 \&$ epa $=\mathrm{SEARCH}$ BOX (July 2019).

Ateneo mercantil de Valencia. Grupo de análisis "Impulso a Valencia", 2014. Actualización del plan Sur de Valencia. http://www.ateneovalencia.es/wp-content/uploads/2014/11/ impulso-a-valencia_actualizaci\%c3\%93n-del-plan-sur-devalencia .pdf (December 2019).

Ayuntamiento de València, 2016. Subvenciones para actuaciones de regeneración y renovación urbanas en el Cabanyal-Canyamelar. Butlletí Oficial de la Provincia de València 139 del 20-VII-2016.

Ayuntamiento de València, 2019. Exposición pública del Plan especial de Cabanyal-Canyamelar. Exp. 03001/2016/000233 (2019/1064) DOGV Num. 8481 del 07.02.2019.

http://www.dogv.gva.es/datos/2019/02/07/pdf/2019_1064.pdf (June 2019).

Basset-Salom, L., Guardiola-Víllora, A., 2020. Seismic Vulnerability and Expected Damage in "ground Zero Are" in El Cabanyal (Valencia), International Journal of Architectural Heritage. DOI: 10.1080/15583058.2019.1710783.

Boira i Maiques, J.V., 2000. Els orígems del Passeig de València al mar: El proyecto de Manuel Sorní de 1865. Cuadernos de geografía, ISSN 0210-086X, No 67-68, 2000, 191-208. 
Cadastral Database: http://www.sedecatastro.gob.es/(July 2019). Claramount Palamos, V., "Calle Mediterráneo" Blog Calles y plazas de Valencia. El origen de sus nombres. http://callesyplazasdevalencia.blogspot.com/search?q=travesia+ del+gas (March 2020)

Collado Lozano, F., 2017. Refugios antiaéreos de la ciudad de Valencia: estudio, propuesta y desarrollo como paisajes culturales urbanos. Espacio, tiempo y forma. Revista de la facultad de Geografía e Historia, serie VI (Geografía) 10: 79 101. DOI: http://dx.doi.org/10.5944/etfvi.10.2017.18725

DOGV, 2017 Diari Oficial de la Generalitat Valenciana $\mathrm{n}^{\circ} 7992$ del 03.03.2017. Bases reguladoras de la concesión de subvenciones para la mejora de las condiciones del interior de las viviendas en el marco del Plan de reforma interior de vivienda. 71f5bdd4.pdf

DOGV, 2018 Diari Oficial de la Generalitat Valenciana $\mathrm{n}^{\circ}$ 8335/10.07.2018. Ayudad de rehabilitación de edificios del Programa de fomento de la conservación, de la mejora de la seguridad de utilización y de la accesibilidad en viviendas del plan estatal de vivienda 2018-2021

http://www.dogv.gva.es/datos/2018/07/10/pdf/2018_6684.pdf)

El Mundo, 2016. Joan Ribó da vía libre para desalojar viviendas ocupadas en el barrio https://www.elmundo.es/comunidadvalenciana/2016/02/09/56b9fc4d268e3e96458b4580.html (January 2020)

Generalitat Valenciana, 2017. Prop de 5 milion d'euros per l'Ârea de Reneragió i Renovacio Urbana del barri del CabanyalCanyamelar de València.

https://www.gva.es/va/inicio/area_de_prensa/not_detalle_area prensa?id=720444 (January 2019)

Herrero García, L.F., 2016. El Cabañal: Permanencias y transformación. PhD Thesis. Doi: 10.4995/Thesis/10251/62201

Hervás Más, J., 2017. El barrio del Cabanyla-Canyameral de Valencia: Historia y futuro. Ciudad y Territorio, Estudios territoriales XLIX (191): 81:97. Ministerio de Fomento.

Las Provincias, 1957. La riada en valencia (14 de octubre de 1957) https://foro.tiempo.com/la-riada-en-valencia-14-deoctubre-de-1957-t62622.0.html (December 2019)

Las Provincias, 2016a. Okupas en el Cabanyal. https://www.lasprovincias.es/valencia-ciudad/201605/20/ denuncias-casas-okupas-duplican-20160519235230.html (January 2020)

Las Provincias, 2016b. El Cabanyal registra 150 inmuebles ocupados. https://www.lasprovincias.es/valenciaciudad/201602/17/cabanyal-registra-inmuebles-ocupados20160217000745-v.html (January 2020)

Las Provincias, 2016c. Las primeras trece viviendas vacías del Cabanyal salen a subasta.

https://www.plancabanyal.es/upload/noticias/dbd9c348.pdf (January 2020)

Las Provincias, 2018. El Ayuntamiento de Valencia ultima la reforma de 14 calles y plazas en el Cabanyal.

https://www.lasprovincias.es/valencia-ciudad/ayuntamientoultima-reforma-20180612130438-nt.html (January 2020)
La Vanguardia, 2016. Desalojo a los okupas del Cabanyal https://www.lavanguardia.com/local/valencia/20160209/302025 755936/valencia-okupas-cabanyal-desalojar.html(January 2020)

Levante-EMV, 2016. A concurso la venta de trece inmuebles del Plan Cabanyal.

https://www.levante-emv.com/valencia/2016/04/20/concursoventa-trece-inmuebles-plan/1406505.html (May 2019)

Levante-EMV, 2017. Nuevo retén de la Policía Local en la "zona cero" del Cabanyal https://www.levante-emv.com/valencia/2017/09/29/instalannuevo-reten-policia-local/1621598.html (January 2020)

Pastor Vila, R., 2012. El Cabanyal. Lectura de las estructuras de la edificación: Ensayo tipológico rsidencial 1900-1936. PhD Thesis, Universitat Politècnica de València.

PEC 2019. Plan especial Cabanyal-Canyamelar. Documentación técnica. http://www.valencia.es/AYUNTAMIENTO/URBANISMO2.N SF/vTramitacionWeb/D1B13E6FF0B4D4DEC1258398002F66 03? OpenDocument\&lang $=1 \&$ nivel $=10 \&$ Categoria $=\& b d o r i g e n=$ ayuntamiento/urbanismo.nsf (March 2019)

Plan Cabanyal-Canyamelar, 2019a. Acuerdo de financiación del ayuntamiento de Valencia.

https://www.plancabanyal.es/upload/noticias/8b332aaf.pdf, (July 2019)

Plan Cabanyal-Canyamelar, 2019b. Actuaciones 2019 para la regeneración y renovación urbana del barrio del CabanyalCanyamelar. https://www.plancabanyal.es/noticias_detalle.php? id=135. (January 2020)

Plan Cabanyal-Canyamelar, 2019c. Demolición del edificio de San Pedro, 107. https://www.plancabanyal.es/noticias _detalle.php?id=139 (October 2019)

Plan Cabanyal-Canyamelar, 2019d Video de la demolición del edificio de San Pedro, 107

https://www.facebook.com/watch/?v=2349194741876353

(November 2019)

Peinado Cucarella, J., 2015. La defensa de la ciudad de Valencia 1936-1939. Una arqueología de la Guerra Civil Española. PhD Thesis. Departament de Prehistòria i Arqueologia. Facultat de Geografia i Història. Universitat de València. Accessed November 22, 2018. http://roderic.uv.es/handle/10550/50253

Pérez Puche, F., 2008. La riada que cambió Valencia. 1957. Riada Cabanyal desde el aire. US Navy https://fppuche.wordpress.com/2017/10/08/la-riada-quecambio-valencia/ (August 2019)

Pinito del oro, 2017. Valencia, riada de 1957. https://prezi.com/hlhlso_4nbco/riada-1957-valencia/(July 2019)

Solé i Sabaté, J., Villarroya, J., 2003. España en llamas. La guerra civil desde el aire. Ediciones Temas de Hoy. ISBN 9788484603023

Tarín, S., 2013. Un Cabanyal torturat. en Las casas del Cabanyal. Modernismo valenciano para el siglo XXI. Valencia: L'Ornella, 8-25. ISBN 978-8496472730 